\title{
Effects of extended absence of flooding on the fish assemblages of three floodplain lagoons in the middle São Francisco River, Brazil
}

\author{
Paulo dos Santos Pompeu* and Hugo Pereira Godinho**
}

In the Neotropics, a large proportion of fish communities of large rivers use floodplain as habitats for feeding, reproduction, and refuge. An evaluation was made of the effects of extended dry periods on the species richness, abundance and local extinction of fish species in three marginal lagoons in the middle São Francisco River, southeastern Brazil. The studied lagoons fail to receive river floods during the study period (1994-1996). A gradual reduction in richness and abundance was observed in all lagoons. Migratory fish species had the highest probability to become extinct in the two lagoons that remained with large water volume. Species tolerant to low levels of dissolved oxygen had the lowest probability of local extinction in the lagoon showing an abrupt reduction in water volume. Similar changes to those observed in the current study are likely to occur in the floodplains if dams would be constructed in this segment of the river. Adequate water releases from Três Marias reservoir, located upstream, should be considered as a management tool for producing episodic flooding on the marginal lagoons of the region.

Na região neotropical uma grande porção da comunidade de peixes utiliza a planície de inundação como habitat de alimentação, reprodução e refúgio. Neste trabalho, foi avaliado o efeito de um período de seca prolongado sobre a diversidade, abundância e extinção local de peixes de três lagoas marginais do médio curso do rio São Francisco. As lagoas estudadas não receberam água proveniente da cheia do rio durante o período de estudos (1994-1996). Redução gradual na abundância e riqueza de peixes foi abservada em todas as lagoas. Nas lagoas que permaneceram com grande volume de água, espécies migradoras foram as que apresentaram maior probabilidade de extinção. Já na lagoa que apresentou abrupta redução no volume de água, espécies tolerantes a baixos níveis de oxigênio dissolvido apresentaram menor probabilidade de extinção local. Caso barragens venham a ser construídas no médio curso do rio São Francisco, mudanças similares às observadas neste estudo poderão ocorrer com maior freqüência na sua planície de inundação. Vertimentos controlados através do reservatório de Três Marias, localizado a montante, devem ser avaliados como ferramenta de manejo para produzir inundações periódicas nas lagoas marginais da região.

Key words: Floodplain, Migratory fish, Extended drought, Hypoxia.

\section{Introduction}

Floodplains are lands periodically covered with water when rivers overflow their banks. In the tropics, a large portion of fish communities uses the floodplains as habitats for feeding, reproduction, and refuge (Agostinho \& Zalewski, 1995; LoweMcConnell, 1999). For this reason, these habitats are priority for fish conservation and management (Costa et al., 1998). During the dry season, the flooded areas become isolated from the main channel of the river, forming numerous marginal lagoons and ponds; some of these lagoons persist until the next flood whereas others dry up. Adaptation to this environmental dynamism allows aquatic and floodplain species to persist in the face of seemingly harsh conditions, such as floods and droughts, that regularly destroy and re-create habitat elements (Poff et al., 1997). In response to the adverse conditions of the dry season, some fishes in marginal lagoons opportunistically change their diet according to the availability of food whereas others tolerate low levels of dissolved oxygen (Machado-Allison, 1994).

Five critical components of the flow regime regulate ecological processes in floodplain ecosystems: the magnitude, frequency, duration, timing and rate of change of hydrological conditions (Poff et al., 1997). Life cycles of the biota utilizing floodplain habitats are intrinsically related to all these components (Junk et al., 1989).

Neotropical floodplains have increasingly been altered through river damming and channeling, and stripping of veg-

*Federal University of Lavras, Departamento de Biologia - Ecologia, 37200-000 Lavras, MG, Brazil. e-mail: pompeu@ufla.br

**Pontifical Catholic University of Minas Gerais, Belo Horizonte, MG, Brazil. 
etation, with direct consequences to the fish fauna (Agostinho \& Zalewski, 1995). Damming directly affects the fish communities, because its changes on the river's flow regimes cause a higher frequency of extended periods without flooding.

This work evaluates the effects of absence of floods on the diversity and abundance (number and biomass) of fish species in three marginal lagoons of the middle São Francisco River, southeastern Brazil. Also, an attempt was made to determine whether the fish species that remained alive during these isolation periods have ecological attributes that distinguish them from those that became locally extinct.

\section{Material and Methods}

Study area. The São Francisco River basin is located between parallels $21^{\circ}$ and $7^{\circ} \mathrm{S}$ and corresponds to $7.4 \%$ of the Brazilian territory. The uses of its waters include power generation, irrigation, industrial and urban water supplies, navigation, and fishing. Located downstream Três Marias dam $\left(45^{\circ} 15^{\prime} 50^{\prime \prime} \mathrm{W} ; 18^{\circ} 15^{\prime} 12^{\prime \prime} \mathrm{S}\right)$, its floodplain occupies approximately 2,000 $\mathrm{km}^{2}$ (Welcomme, 1990). Its importance as fish nurseries and role in recruitment of migratory species have been long recognized (Menezes, 1956).

The three lagoons under study, 'Curral-de-Vara', 'Cajueiro' and 'Juazeiro', are located in the medium São Francisco River region, $600 \mathrm{~km}$ downstream Três Marias dam, in a stretch rich in marginal lagoons (Fig. 1). The lagoons were connected to the river during the previous rainy season (January 1994) and remained isolated throughout the study period. Curral-deVara and Cajueiro retained a large volume of water during this period, and their oxygen concentrations were always greater

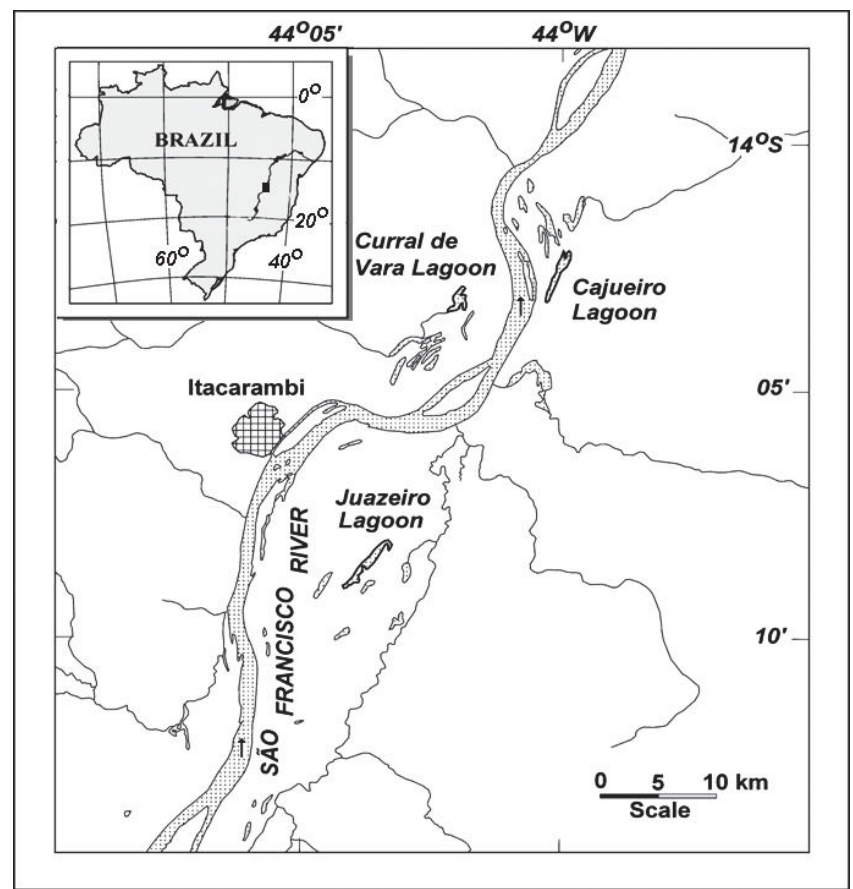

Fig. 1. Study area showing the location of the marginal lagoons. than $5 \mathrm{mg} \times \mathrm{l}^{-1}$ (Pompeu, 1997). However, Juazeiro showed a significant loss in water volume; in September 1995, it had a very small water surface and low oxygen concentration (2 $\mathrm{mg} \times \mathrm{l}^{-1}$ ) (Pompeu, 1997) and subsequently dried up.

Sampling and analyses. Four field trips for collecting fishes were made over a period of two years (1994-1996), comprising dry (September/1994 and September/1995) and wet seasons (March/1995 and March/1996). In each trip (three days), gill nets (mesh sizes 3, 4, 5, 6, 7, 8, 10, 12, 14 and $16 \mathrm{~cm}$ opposite knots) were set between 10:00 and 14:00h and between 17:00 and 21:00h. For capturing smaller fishes, dragnets of $1 \mathrm{~mm}$ mesh size were used during the morning and afternoon. Drag netting was the only capture method used in the Juazeiro lagoon in September 1995. Since no recolonization by flooding occurred during the period of study, the fish richness of each lagoon was represented by all species captured along the period of study.

After being captured, the fishes were immediately fixed in $10 \%$ formaldehyde solution and subsequently preserved in $70 \%$ ethanol solution. In the laboratory, each fish was weighed, measured for standard length and identified. Catch per unit of effort (CPUE) in number (CPUEn) and in biomass (CPUEb) was used to express data on numerical abundance (number of individuals per $10 \mathrm{~m}^{2}$ of net in $8 \mathrm{~h}$; CPUEn) and biomass (grams per $10 \mathrm{~m}^{2}$ of net in $8 \mathrm{~h}$; CPUEb).

To determine whether fish abundance decreased over the dry period, differences in total CPUE were tested using ANOVA (SAS, 1985), and Tukey test was used as a post hoc procedure. Since an abrupt reduction in the water volume occurred in the Juazeiro lagoon between March/1995 and September/1995, it was impossible to use gillnets in the September/1995 field trip. Thus, the tests of CPUE differences were conducted only on data from the Curral-de-Vara and Cajueiro lagoons.

To determine whether the species that survived during the period of lagoon isolation had biological characteristics that distinguished them from the extinct ones, the following ecological attributes were compared:

a) Standard length - the fish species were grouped into the following categories, according to the standard length of the largest individual captured: class $1=\mathrm{SL}<5 \mathrm{~cm}$; class $2=5 \mathrm{~cm} \leq$ $\mathrm{SL}<15 \mathrm{~cm}$; class $3=15 \mathrm{~cm} \leq \mathrm{SL}<30 \mathrm{~cm}$; and class $4=\mathrm{SL} \geq 30 \mathrm{~cm}$;

b) Reproductive migratory trait - 1 was attributed to the migratory species and 0 to the non-migratory species;

c) Trophic category - numerical values were attributed to each category according to Angermeier (1995). Thus, $1=$ detritivore and herbivore, $3=$ invertivore and $5=$ piscivore. For the species classified in more than one trophic category, the value corresponded to the average between them (e.g., 4 $=$ invertivore-piscivore).

d) Hypoxia tolerance - 0 was attributed to tolerant species and 1 to non-tolerant species.

Associations between the ecological attributes and local extinction were examined using Fisher's exact test (Fleiss, 1981). Biological segregation between groups of non-extinct and ex- 
tinct species was made through multiple logistic regression, which was also used for calculating the odds ratio. For this analysis, the standard length was considered as a continuous variable. The odds ratio is equal to the extinction probability ratio between two groups of species (e.g., migratory and nonmigratory), calculated according to Hosmer \& Lemeshow (1989):

$O R=e^{\beta i}$, where:

$O R=$ odds ratio for variable $i$,

$\beta=$ regression coefficient for variable $i$.

Statistical significance was indicated by P-values of 0.05 or less.

Since the lagoons were connected to the river during 1993/ 1994 and 1996/1997 rainy seasons, the minimal São Francisco River flow enough to flood the study area was estimated from the maximum monthly discharge during that period. The minimal flow frequency was evaluated for a period of 20 years before and after the construction of Três Marias Dam, closed in 1961. The data were obtained from the meteorological station of Manga Municipality, State of Minas Gerais, the nearest city to the study area.

\section{Results}

A total of 11,072 fishes belonging to 48 species were captured; of those, 1,511 were captured by gill nets and 9,561 by dragnets. Their ecological attributes are indicated in Table 1. The Curral-de-Vara lagoon showed greater number of species (44) than Cajueiro and Juazeiro lagoons (34). A gradual reduction in species richness was observed in all lagoons along the period of study (Fig. 2). Curral-de-Vara and Cajueiro also showed a gradual decrease in CPUEn (Fig. 3) and CPUEb values during the same period (Fig. 4), the latter being significant $(\mathrm{P}<0.05)$.

Standard length and trophic category of the non-extinct species were not significantly different from those of the extinct ones (Table 2). At Cajueiro, the migratory species became extinct at a significantly higher rate $(\mathrm{P}<0.05)$ than the non-migratory species. In the other lagoons, although a relation between migration and local extinction was also observed, the differences in the extinction rates between these two groups were not significant $(\mathrm{P}>0.05)$ (Table 2). In the Juazeiro lagoon, species tolerant to hypoxia had significantly greater chance of survival than the non-tolerant ones (Table 2).

Although the logistic regression model was significant only for the Juazeiro, the analyses indicated that in all lagoons, the migratory species had at least 10 times more chances of becoming extinct. In the Juazeiro lagoon, in addition, the probability of extinction of the species with no tolerance to low dissolved oxygen levels was approximately $10^{9}$ times higher (Table 3 ).

Considering that the lagoons were connected to the river during the rainy seasons of 1993/1994 and 1996/1997 and not in 1994/1995 and 1995/1996, the minimal river flow enough to flood the study area was calculated to be approximately 5,000 $\mathrm{m}^{3} \times \mathrm{s}^{-1}$. After Três Marias dam closure (1959), the frequency

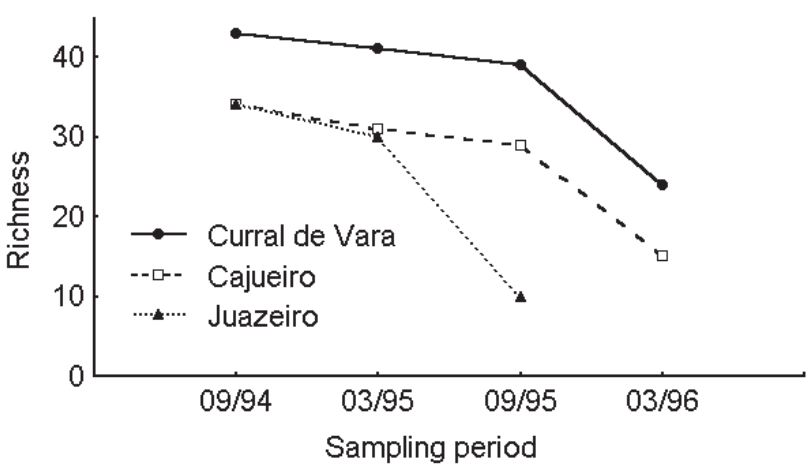

Fig. 2. Fish richness in the marginal lagoons of the middle São Francisco River, Brazil, from September 1994 to March 1996.

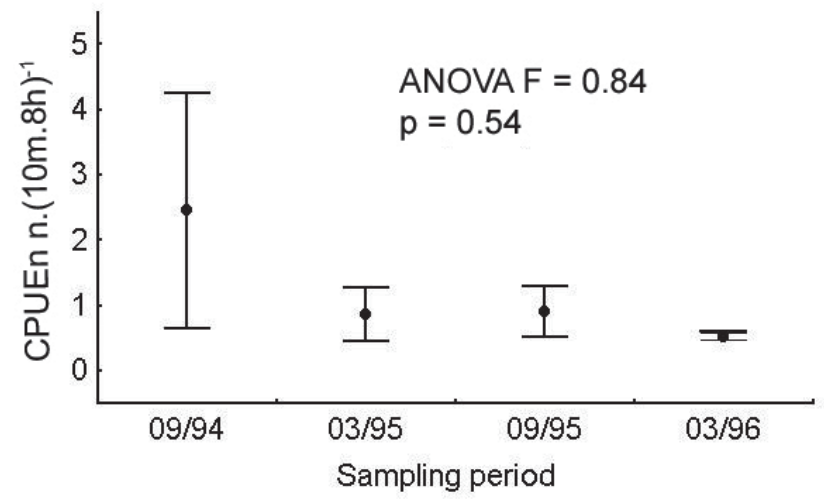

Fig. 3. Catch per unit of effort in number of individuals (CPUEn) in the 'Curral-de-Vara' and 'Cajueiro' lagoons of the middle São Francisco River, Brazil, from September 1994 to March $1996(\mathrm{dot}=$ mean; whiskers $=$ maximum and minimum $)$.

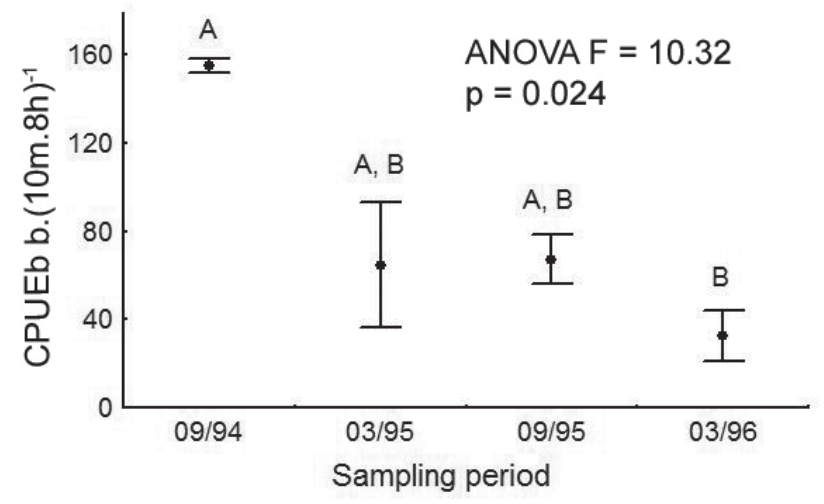

Fig. 4. Catch per unit of effort in biomass (CPUEb) in the 'Curral-de-Vara' and 'Cajueiro' lagoons of the middle São Francisco River, Brazil, from September 1994 to March 1996 (dot = mean; whiskers $=$ maximum and minimum). Different letters above columns indicate significant differences. 
Table 1. Ecological attributes of the fishes captured in the 'Curral-de-Vara', 'Cajueiro' and 'Juazeiro' lagoons, São Francisco River, from September, 1994 to March, 1996. Species denomination followed Reis et al., 2003; 1: Sato et al. (1987), Lamas (1993); 2: Pompeu \& Godinho (2003); 3: Carter \& Beadle (1931), Bastos (1956), Driedzic et al. (1978), Hochachka et al. (1978), Kramer et al. (1978), Acuña \& Sanz (1992), Rantin et al. (1992), Machado-Allison (1994); $\mathrm{N}=$ non-migratory, $\mathrm{Y}=$ migratory, $\mathrm{U}=$ migratory trait unknown; herb = herbivore, invert = invertivore, detri = detritivore; $\mathrm{N}=$ hypoxia intolerant, $\mathrm{Y}=$ hypoxia tolerant.

\begin{tabular}{|c|c|c|c|c|}
\hline Species & $\begin{array}{c}\text { Maximum } \\
\text { standard } \\
\text { length }(\mathrm{cm})\end{array}$ & $\begin{array}{l}\text { Migratory } \\
\text { Behavior }^{1}\end{array}$ & $\begin{array}{c}\text { Trophic } \\
\text { category }^{2}\end{array}$ & $\begin{array}{l}\text { Hypoxia } \\
\text { tolerance }^{3}\end{array}$ \\
\hline Acestrorhynchus britskii Menezes, 1969 & 17.3 & $\mathrm{~N}$ & piscivore & $\mathrm{N}$ \\
\hline Acestrorhynchus lacustris (Lütken, 1875) & 23.4 & $\mathrm{~N}$ & piscivore & $\mathrm{N}$ \\
\hline Anchoviella vaillanti (Steindachner, 1908) & 3.6 & $\mathrm{~N}$ & invertivore & $\mathrm{N}$ \\
\hline Astyanax sp. & 3.8 & $\mathrm{~N}$ & herb-invert & $\mathrm{N}$ \\
\hline Astyanax fasciatus (Cuvier, 1819) & 4.4 & $\mathrm{~N}$ & invertivore & $\mathrm{N}$ \\
\hline Astyanax bimaculatus (Linnaeus, 1758) & 7.0 & $\mathrm{~N}$ & herb-invert & $\mathrm{N}$ \\
\hline Brycon orthotaenia Günther, 1864 & 24.0 & $\mathrm{Y}$ & herbivore & $\mathrm{N}$ \\
\hline Bryconamericus stramineus Eigenmann, 1908 & 4.2 & $\mathrm{~N}$ & herb-invert & $\mathrm{N}$ \\
\hline Characidium sp. & 2.9 & $\mathrm{~N}$ & invertivore & $\mathrm{N}$ \\
\hline Cichla temensis Humboldt, 1821 & 34.4 & $\mathrm{~N}$ & piscivore & $\mathrm{N}$ \\
\hline Cichlasoma sanctifranciscense Kullander, 1983 & 4.6 & $\mathrm{~N}$ & invertivore & $\mathrm{N}$ \\
\hline Crenicichla lepidoda Heckel, 1840 & 8 & $\mathrm{~N}$ & invertivore & $\mathrm{N}$ \\
\hline Curimatella lepidura Eigenmann \& Eigenmann, 1889 & 11.0 & $\mathrm{~N}$ & detritivore & $\mathrm{N}$ \\
\hline Eigenmannia virescens (Valenciennes, 1842) & 25.5 & $\mathrm{~N}$ & invertivore & $\mathrm{N}$ \\
\hline Gymnotus carapo Linnaeus, 1758 & 26.2 & $\mathrm{~N}$ & invertivore & $\mathrm{Y}$ \\
\hline Hemigrammus marginatus Ellis, 1911 & 3.1 & $\mathrm{~N}$ & invertivore & $\mathrm{N}$ \\
\hline Hoplerythrinus unitaeniatus (Agassiz, 1829) & 24.6 & $\mathrm{U}$ & detri-herb & Y \\
\hline Hoplias malabaricus (Block, 1794) & 31.3 & $\mathrm{~N}$ & piscivore & Y \\
\hline Hoplosternum littorale (Hancock, 1828) & 18.8 & $\mathrm{~N}$ & detri-invert & $\mathrm{Y}$ \\
\hline Hyphessobrycon santae (Eigenmann, 1907) & 2.2 & $\mathrm{U}$ & invertivore & $\mathrm{N}$ \\
\hline Leporinus piau Fowler, 1941 & 20.5 & $\mathrm{~N}$ & herb-pisci & $\mathrm{N}$ \\
\hline Leporinus renhardti Lütken, 1875 & 17.0 & $\mathrm{Y}$ & invertivore & $\mathrm{N}$ \\
\hline Leporinus taeniatus Lütken, 1875 & 10.8 & $\mathrm{Y}$ & herbivore & $\mathrm{N}$ \\
\hline Hyphessobrycon micropterus Eigenmann, 1915 & 2.60 & $\mathrm{U}$ & invertivore & $\mathrm{N}$ \\
\hline Moenkhausia costae (Steindachner, 1907) & 5.7 & $\mathrm{~N}$ & invertivore & $\mathrm{N}$ \\
\hline Myleus micans (Lütken, 1875) & 15.0 & $\mathrm{U}$ & invertivore & $\mathrm{N}$ \\
\hline Orthospinus franciscensis (Eigenmann, 1914) & 9.0 & $\mathrm{~N}$ & invertivore & $\mathrm{N}$ \\
\hline Phenacogaster franciscoensis Eigenmann, 1911 & 3.4 & $\mathrm{U}$ & invertivore & $\mathrm{N}$ \\
\hline Pimelodella cf. vittata (Lütken, 1874) & 5.6 & $\mathrm{~N}$ & invertivore & $\mathrm{N}$ \\
\hline Pimelodus maculatus La Cepède, 1803 & 23.0 & $\mathrm{~N}$ & invertivore & $\mathrm{N}$ \\
\hline Pimelodus pohli Ribeiro \& Lucena, 2006 & 16.0 & $\mathrm{~N}$ & invertivore & $\mathrm{N}$ \\
\hline Pamphorichthys hollandi (Henn, 1916) & 2.8 & $\mathrm{U}$ & herb-invert & $\mathrm{N}$ \\
\hline Prochilodus costatus Valencienes, 1850 & 23.3 & $\mathrm{Y}$ & detritivore & $\mathrm{N}$ \\
\hline Prochilodus argenteus Agassiz, 1829 & 36.6 & $\mathrm{Y}$ & detritivore & $\mathrm{N}$ \\
\hline Psellogrammus kennedyi (Eigenmann, 1903) & 4 & $\mathrm{U}$ & herb-invert & $\mathrm{N}$ \\
\hline Pseudoplatystoma corruscans (Spix \& Agassiz, 1829) & 68.0 & $\mathrm{Y}$ & piscivore & $\mathrm{N}$ \\
\hline Pterygoplichthys etentaculatus (Spix \& Agassiz, 1829) & 23.4 & $\mathrm{U}$ & herbivore & $\mathrm{Y}$ \\
\hline Pygocentrus piraya (Cuvier, 1819) & 31.0 & $\mathrm{~N}$ & piscivore & $\mathrm{N}$ \\
\hline Roeboides xenodon (Reinhardt, 1851) & 9.4 & $\mathrm{~N}$ & invertivore & $\mathrm{N}$ \\
\hline Salminus sp. & 58.0 & $\mathrm{Y}$ & piscivore & $\mathrm{N}$ \\
\hline Schizodon knerii (Steindachner, 1875) & 27.3 & $\mathrm{~N}$ & herbivore & $\mathrm{N}$ \\
\hline Serrapinnus piaba (Lütken, 1875) & 3.3 & $\mathrm{~N}$ & herb-invert & $\mathrm{N}$ \\
\hline Serrapinnus heterodon (Eigenmann, 1915) & 3.1 & $\mathrm{U}$ & herb-invert & $\mathrm{N}$ \\
\hline Serrasalmus brandtii Lütken, 1875 & 18.0 & $\mathrm{~N}$ & invert-pisc & $\mathrm{N}$ \\
\hline Synbranchus marmoratus Bloch, 1795 & 17 & $\mathrm{U}$ & piscivore & $\mathrm{Y}$ \\
\hline Tetragonopterus chalceus Spix \& Agassiz, 1829 & 9.0 & $\mathrm{~N}$ & invertivore & $\mathrm{N}$ \\
\hline Trachelyopterus galeatus (Linnaeus, 1766) & 16.5 & $\mathrm{~N}$ & invertivore & $\mathrm{Y}$ \\
\hline Triportheus guentheri (Garman, 1890) & 12.4 & $\mathrm{~N}$ & invertivore & $\mathrm{N}$ \\
\hline
\end{tabular}

of occurrence of such flow was notably lower due to its regulatory influence (Figs. 5 and 6).

\section{Discussion}

The fish richness of a lake is limited by the species capacity to persist and coexist and it results from the equilibrium between colonization and losses through local extinction (Barbour \& Brown, 1974). Fish colonization in marginal lagoons generally occurs during the rainy (flooding) season and extinction during the dry season (Halyc \& Balon, 1983). During the dry season, there are high levels of predation, reduction in food availability and quality, and, in some cases, decreased oxygen availability and dryness (Junk et al., 1989). All these factors may have influenced the probability of species extinction and played a significant role in fish richness and abundance decrease in the analyzed lagoons during the period of isolation. Richness was also strongly correlated with the lagoon's isolation time from the main river in Pantanal (Súarez et. al., 2004), and differences in frequency and inten- 
Table 2. Number of extinct species (maximum number of species) by ecological attribute and the respective extinction probability for three marginal lagoons of the middle São Francisco River during the dry periods of 1994 to 1996.

\begin{tabular}{|c|c|c|c|c|c|c|}
\hline Marginal lagoon & \multicolumn{5}{|c|}{ Ecological Atribute } & $\begin{array}{c}\text { Probability } \\
\end{array}$ \\
\hline \multicolumn{7}{|c|}{ Maximum standard length $(\mathrm{cm})$} \\
\hline & $>5$ & $5-15$ & & & $>30$ & \\
\hline Curral-de-Vara & $9(13)$ & $2(10)$ & & & $2(5)$ & 0.114 \\
\hline Cajueiro & $5(10)$ & $5(5)$ & & & $3(6)$ & 0.191 \\
\hline Juazeiro & $7(9)$ & $6(7)$ & & & $2(3)$ & 0.712 \\
\hline \multicolumn{7}{|c|}{ Trophic category } \\
\hline & $\begin{array}{l}\text { Detritivore/her } \\
\text { bivore }\end{array}$ & $\begin{array}{l}\text { Detritivore/inv } \\
\text { ertivore }\end{array}$ & Invertivore & $\begin{array}{l}\text { Invertivore/ } \\
\text { piscivore }\end{array}$ & Piscivore & \\
\hline Curral-de-Vara & $5(8)$ & $5(8)$ & $7(19)$ & $0(0)$ & $2(8)$ & 0.355 \\
\hline Cajueiro & $3(5)$ & $2(5)$ & $11(16)$ & $0(1)$ & $4(7)$ & 0.159 \\
\hline Juazeiro & $5(6)$ & $2(6)$ & $12(15)$ & $0(0)$ & $3(7)$ & 0.348 \\
\hline \multicolumn{7}{|c|}{ Reproductive trait } \\
\hline & & Iigratory & & Non-migra & & \\
\hline Curral-de-Vara & & $5(7)$ & & $14(36)$ & & 0.121 \\
\hline Cajueiro & & $5(6)$ & & $9(28)$ & & 0.032 \\
\hline Juazeiro & & $4(4)$ & & $20(30)$ & & 0.229 \\
\hline \multicolumn{7}{|c|}{ Tolerance to hypoxia } \\
\hline & & Tolerant & & Non-toler & & \\
\hline Curral-de-Vara & & $2(4)$ & & 18(39) & & 0.641 \\
\hline Cajueiro & & $3(5)$ & & $15(28)$ & & 0.591 \\
\hline Juazeiro & & $0(7)$ & & $24(27)$ & & $<0.001$ \\
\hline
\end{tabular}

sity of communication between the lagoons and the river were determinant for the species richness in an isolated lagoon of the Upper Paraná River floodplain (Cunico et. al., 2004). Smaller fish catches during the dry season were also observed in marginal lagoons of the Paraná River (Bonetto et al., 1969; Cordiviola de Yuan, 1992).

Regarding the probability of maintenance in the lagoon during the period of isolation, the extinction rate was higher among the migratory species, than the non-migratory ones. In addition to being unable to reproduce in the lagoons, migratory fish are target fisheries species due to their large size and commercial value. In the Upper Paraná River floodplain lagoon, the density of migratory fish was also lower in a year characterized by low water levels, short inundation period

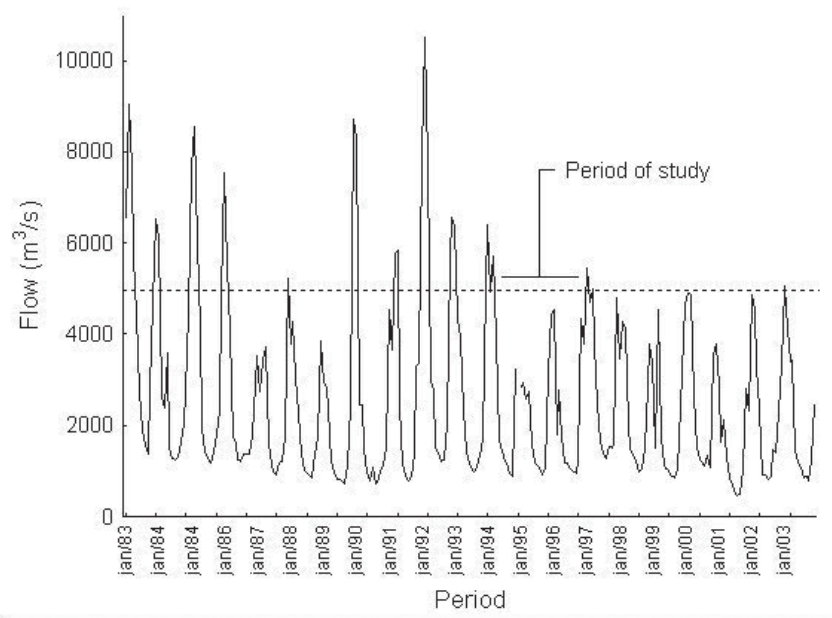

Fig. 5. São Francisco River flow at the town of Manga, State of Minas Gerais, during the last 20 years before 2003, including the period of study. and interrupted floods (Cunico et. al., 2004).

Some fishes can tolerate low dissolved oxygen levels that frequently occur in floodplains during the dry season (Machado-Allison, 1994). In Lake Camaleão (Amazon River basin), which shows oxygen deficits during long periods, at least a quarter of its species can live in waters with very low dissolved oxygen concentrations (Junk et al., 1983). In Pantanal, species that remain in isolated lagoons are represented by: (1) individuals that fail to return (or fail to have the opportunity) to the river before isolation, and (2) species that would exhibit some adaptation to the pool characteristics (e.g. hypoxia, presence/absence of sheltering macrophytes, desiccation), and therefore may be able to survive until the next flood (Catella, 1992).

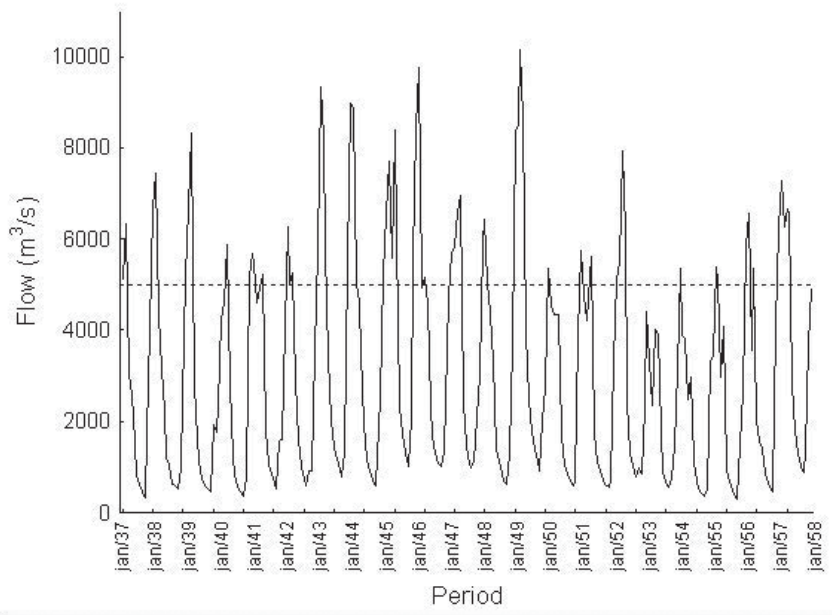

Fig. 6. São Francisco River flow at the town of Manga, State of Minas Gerais, during 20 years before the closure of Três Marias Dam. 
Table 3. Summary of multiple logistic regression models for each lagoon of the middle São Francisco River.

\begin{tabular}{lrccc}
\hline Lagoon/variable & Estimator & $-2 \log \mathrm{L}$ & Probability & Odds ratio \\
\hline Curral-de-Vara & & & & \\
$\quad$ length & -0.046 & & 0.223 & 0.956 \\
migration & 2.551 & & 0.089 & 12.82 \\
feeding & -0.028 & & 0.933 & 0.973 \\
hypoxia & -0.976 & & 0.395 & 0.377 \\
model & & 5.056 & 0.282 & \\
& & & & \\
Cajueiro & & & & \\
length & -0.044 & & 0.288 & 0.957 \\
migration & 2.343 & & 0.179 & 10.41 \\
feeding & -0.035 & & 0.924 & 0.965 \\
hypoxia & -1.079 & & 0.329 & 0.340 \\
model & & 3.064 & 0.547 & \\
& & & & \\
Juazeiro & & & & \\
length & 0.178 & & 0.323 & 1.195 \\
$\quad$ migration & 12.01 & & $<0.001$ & $1.6 \times 10^{5}$ \\
feeding & 0.616 & & 0.565 & 1.852 \\
hypoxia & 22.00 & & $<0.001$ & $3.5 \times 10^{9}$ \\
model & & 26.25 & $<0.001$ & \\
\hline
\end{tabular}

Tolerance to hypoxic conditions was apparently a determinant for the survival of the species in the Juazeiro lagoon, following the marked reduction of its water volume. Of the seven species that survived, four are capable of breathing atmospheric oxygen (H. unitaeniatus: Driedzic et al., 1978; M. etentaculatus: Carter \& Beadle, 1931, Kramer et al., 1978; H. littorale: Carter \& Beadle, 1931; and S. marmoratus: Kramer et al., 1978). Hoplosternum littorale, in addition to breathing atmospheric oxygen, shows blood cell modifications that ensure greater efficiency during hypoxia (Acuña \& Sanz, 1992). Although not breathing atmospheric oxygen, Hoplias malabaricus tolerates very low oxygen levels, it needs little water convection to breathe (Rantin et al., 1992) and it has a large respiratory gill surface area (Driedzic et al., 1978; Hochachka et al., 1978). Since the trophic position and maximum size of the species are unrelated to their chances of local extinction, the number of locally extinct species in each size class or trophic category may have reflected an inherent characteristic of the fish fauna rather than a predisposition to extinction.

Losses of fish biomass resulting from dryness are estimated for the middle Paraná River to be $40,000 \mathrm{t}$ of fish $\times$ year $^{-1}$ (Bonetto et al., 1969), and to be related to flow intensity (Cunico et al., 2004). Although drought is a natural phenomenon, additional impacts due to long periods of flood absence caused by anthropic actions cannot be discarded. The flood regime differentially affects reproduction and recruitment of species of different life histories. Dependence of flooding seems to be lower for sedentary species with parental care when compared with migratory species that spawn in upper basin stretches and whose young inhabit flood areas during their initial development (Agostinho et al., 2004). As a consequence, river regulation by dams may impose drastic constraints on migratory fish and on those that spawn in floodplains with important consequences for commercial fish- ing (Sato \& Godinho, 2003; Agostinho et al., 2003; 2004).

If the flooding that preceded the period covered by the current work was an unusual event, it would have filled the lagoons with an unusually large number of species and biomass. Then, the subsequent decline would be merely the relaxation of the system back to a natural level. However, the 1993/ 1994 flooding was not exceptional, but a very common one (see Fig. 5). The reduction in the water level fluctuation in the middle São Francisco River resulting from Três Marias dam may be causing an important impact on the natural functioning of its floodplains. Considering new dam constructions in the main river and tributaries, a possibility that appears in different governmental proposals, similar changes to those observed in the marginal lagoons of the current work would likely become permanent conditions. Taking into account the current observations, water releases from Três Marias reservoir during the rainy season should be assessed as a management tool for periodic flooding of the marginal lagoons in the region (Godinho et al., 2003), with potential to improve recruitment of migratory species. In addition, mitigatory water releases from new dams should be taken as part of the adopted measures to reduce impacts on downstream flow.

\section{References}

Acuña, M. L. \& M. Sanz. 1992. Estudio preliminar sobre las variaciones de la citomorfologia sanguinea del pez de agua dulce Hoplosternum littorale sometido a hipoxia experimental. Acta Biologica Venezolana 13: 53-63.

Agostinho, A. A. \& M. Zalewski. 1995. The dependence of fish community struture and dynamics on floodplain and riparian ecotone zone in Parana River, Brazil. Hydrobiologia 303: 141-148.

Agostinho, A. A., L. C. Gomes, H. I. Suzuki \& H. F. Júlio Jr. 2003. Migratory fishes of the upper Paraná River basin, Brazil. In: Carolsfeld J., B. Harvey \& C. Ross (Eds) Migratory fishes of South America: biology, fisheries and conservation status. Victoria, Canada, International Development Research Centre (Canada)/World Bank. 372p.

Agostinho, A. A., L. C. Gomes, S. Veríssimo \& E. K. Okada. 2004. Flood regime, dam regulation and fish in the Upper Paraná River: effects on assemblage attributes, reproduction and recruitment. Reviews in Fish Biology and Fisheries 14: 11-19.

Angermeier, P. L. 1995. Ecological attributes of extintion-prone species: loss of freshwater fishes of Virginia. Conservation Biology 9: 143-158.

Barbour, C. D. \& J. H. Brown. 1974. Fish species diversity in lakes. American Naturalist 108: 473-489.

Bastos, J. A. M. 1956. Consumo e taxa mínima de oxigênio do apaiari Astronotus ocellatus (Spix); cangati Trachycorystes sp. e corvina, Plagioscion squamosissimus (Heckel). Revista Brasileira de Biologia 16: 103-114.

Bonetto, A. A., E. Cordiviola de Yuan, C. Pignalberi \& O. Oliveros. 1969. Ciclos hidrologicos del rio Parana y las poblaciones de peces contenidas en las cuencas temporarias de su valle de inundacion. Physis 78: 213-223.

Carter, G. S. \& L. C. Beadle. 1931. The fauna of the swamps of the Paraguayan Chaco in relation to its enviromnent - II. Respiratory adaptations in the fishes. Journal of the Linnean Society of London (Zoology) 37: 327-368. 
Catella, A. C. 1992. Estrutura da comunidade e alimentação dos peixes da Baía da Onça, uma lagoa do pantanal do rio Aquidauana-MS. Unpublished Master Thesis. UNICAMPI, Campinas. 215p.

Cordiviola de Yuan, E. 1992. Fish populations of lentic environments of the Paraná River. Hydrobiologia 237: 159-173.

Costa, C. M. R., G. Herrmann, L. V. Lins \& I. R. Lamas. 1998. Biodiversidade em Minas Gerais: um atlas para sua conservação. Belo Horizonte: Fundação Biodiversitas. 94p.

Cunico, A. M., W. J. da Graça, S. Veríssimo \& L. M. Bini. 2002. Influência do nível hidrológico sobre a assembléia de peixes em lagoa sazonalmente isolada da planície de inundação do alto rio Paraná. Acta Scientiarum 24: 383-389.

Driedzic, W. R., C. F. Phleger, J. H. A. Fields \& C. French. 1978. Alterations in energy metabolism associated with the transition from water to air breathing in fish. Canadian Journal of Zoology 56: 730-735.

Fleiss, J. R. 1981. Statistical methods for rates and proportions. ( $2^{\text {nd }}$ ed.). John Wiley \& Sons, New York. 321p.

Halyc, L. C. \& E. K. Balon. 1983. Structure and ecological production of the fish taxocene of a small floodplain system. Canadian Journal of Zoology 61: 2446-2464.

Hochachka, P. W., M. Guppy, H. E. Guderley, K. B. Storey \& W. C. Hulbert. 1978. Metabolic biochemistry of water-vs. airbreathing fishes: muscle enzymes and ultraestructure. Canadian Journal of Zoology 56: 736-750.

Hosmer, D. W. \& S. Lemeshow. 1989. Applied logistic regression. J. Wiley, New York._307p.

Junk, W. J., P. B. Bayley \& R. E. Sparks. 1989. The flood pulse concept in river-floodplain systems. Canadian Special Publications of Fisheries and Aquatic Sciences 106: 110-127.

Junk, W. J., G. M. Soares \& F. M. Carvalho. 1983. Distribution of fish species in a lake of the Amazon River floodplain near Manaus (lago Camaleão), with special reference to extreme oxygen conditions. Amazoniana 7: 397-431.

Kramer, D. L., C. C. Lindsey, G. E. E. Moodie \& E. D. Stevens. 1978. The fishes and the aquatic environment of the central Amazon basin, with particular reference to respiratory patterns. Canadian Journal of Zoology 56: 717-729.

Lamas, I. R. 1993. Análise de características reprodutivas de peixes de água doce, com ênfase no local de desova. Unpublished Master Thesis. Federal University of Minas Gerais, Belo Horizonte. 72p.

Lowe-McConnell, R. L. 1999. Estudos ecológicos de comunidades de peixes tropicais. EDUSP, São Paulo. 535p.
Machado-Allison, A. 1994. Factors affecting fish communities in the flooded plains of Venezuela. Acta Biologica Venezuelana 15: 59-75.

Menezes, R. S. 1956. Pesca e piscicultura no vale do São Francisco. Boletim da Secretaria da Agricultura, Indústria e Comércio do Estado de Pernambuco 23: 43-105.

Poff, N. L., J. D. Allan, M. B. Bain, J. R. Karr, K. L. Prestegaard, B. D. Richter, R. E. Sparks \& J. C. Stromberg. 1997. The natural flow regime: a paradigm for river conservation and restoration. Bioscience 47: 769-783.

Pompeu, P. S. \& H. P. Godinho. 2003. Dieta e estrutura trófica das comunidades de peixes de três lagoas marginais do médio rio São Francisco. pp. 183-194. In: Godinho H. P. \& A. L. Godinho (Eds) Águas, peixes e pescadores do São Francisco das Gerais. Belo Horizonte: PUC Minas. 468p.

Pompeu, P. S .1995. Efeitos das estações seca e chuvosa e da ausência de inundações nas comunidades de peixes de três lagoas marginais do médio São Francisco Unpublished Master Thesis. Federal University of Minas Gerais, Belo Horizonte. 72p.

Rantin, F. T., A. L. Kalinin, M. L. Gladd \& M. N. Fernandes. 1992. Respiratory responses to hypoxia in relation to mode of life of two erythrinid species (Hoplias malabaricus and Hoplias lacerdae). Journal of Fish Biolology 41: 805-812.

Reis, R. E., S. O. Kullander \& C. J. Ferraris Jr. 2003. Check list of the freshwater fishes of South and Central America. Porto Alegre: EDIPUCRS. 742p.

SAS. 1985. SAS user's guide; statistic version, $5^{\text {th }}$ ed. Cary, NC, SAS Institute Inc. 956p.

Sato, Y., E. L. Cardoso \& J. C. C. Amorim. 1987. Peixes das lagoas marginais do São Francisco a montante da represa de Três Marias (Minas Gerais). CODEVASF, Brasília. 42p.

Sato, Y. \& H. P. Godinho. 2003. Migratory fishes of the São Francisco river basin, pp. 195-132. In: Carolsfeld, J., B. Harvey \& C. Ross (Eds). Migratory fishes of South America: biology, fisheries and conservation status. Victoria, Canada, International Development Research Centre (Canada)/World Bank. 372p.

Súarez, Y. R., M. Petrere Jr. \& A. C. Catella. 2004. Factors regulating diversity and abundance of fish communities in Pantanal lagoons, Brazil. Fisheries Management and Ecology 11: 45-50.

Welcomme, R. L. 1990. Status of fisheries in South American rivers. Interciencia 15: 337-345.

Submitted May 2006 Accepted November 2006 